\title{
ZARYS FENOMENOLOGII SOLIDARNOŚCI: O GENEZIE KONSTYTUOWANIA SIĘ GRUP
}

\begin{abstract}
Streszczenie. Artykuł jest próbą sformułowania fenomenologii solidarności jako zjawiska społecznego. Autor odróżnia solidaryzację subiektywną od intersubiektywnej, podkreślając, że w tym drugim przypadku ma się do czynienia z konstytucją grup. Artykuł jest podzielony na trzy zasadnicze części. W pierwszej z nich analizuje się tzw. problem mostu, czyli prezentuje się zasadność przejścia od analizy solidaryzacji subiektywnej do intersubiektywnej. Punktem wyjścia są przy tym teorie Ingardena i Tischnera. Następnie prezentuje się opis struktury i elementów solidarności jako aktu złożonego. Na tej podstawie autor formułuje zarys alternatywnego ujęcia solidarności jako konstytucji grup i odniesienia się do świata jako wspólnego.
\end{abstract}

Słowa kluczowe: solidarność, solidaryzacja, wspólnotowość, konstytucja, intencjonalność kolektywna, Husserl

1. Wprowadzenie: pierwsze dystynkcje pojęciowe. 2. Od solidaryzacji egotycznej do społecznej: problem mostu. 3. Elementy struktury aktu solidaryzowania się jako aktu złożonego. 4. Genetyczne ujęcie solidarności: jak konstytuuje się grupa? 5. Zakończenie.

\section{WPROWADZENIE: PIERWSZE DYSTYNKCJE POJĘCIOWE}

Solidarność oraz solidaryzowanie się są zjawiskami złożonymi i przybierają różne formy. Solidarność, mówiąc ściśle, jest przedmiotowym korelatem procesu, czy też aktu solidaryzowania się. Traktując solidaryzowanie się en bloc, można je ogólnie ująć jako, dajmy na to, zgodność, jednomyślność, akceptację, wzajemne się wspieranie, czy też jako współodpowiedzialność za coś lub kogoś, ewentualnie jako afirmację czegoś lub kogoś. Tak jak solidaryzowanie może przybierać różne formy, również solidarność jest wieloznaczna. Wydaje się jednak, że wprowadzając pierwsze dystynkcje pojęciowe, można zaryzykować opis solidarności jako pewnej (a) relacji pomiędzy 
(b) podmiotem, osobq lub dziatajacym i (c) czymś (np. wartością) lub (d) kimś. Solidaryzowanie się podmiotu z czymś można nazwać solidarnościq przedmiotowa, zaś z kimś- solidarnościq podmiotowa lub osobową. Co ważne podkreślenia, może przybierać charakter (e) pozytywny lub $(f)$ negatywny. W tym ostatnim przypadku ma się do czynienia z desolidaryzacja, którą jest niezgodność, odrzucenie i protest. Niezależnie od tego, solidaryzowanie się może konstytuować dwie formy solidarności: $(g)$ solidarności subiektywnej, gdy mówi się o pojedynczym podmiocie, osobie lub działającym oraz (b) solidarności intersubiektywnej, gdy zjawisko to dotyczy dwóch lub więcej podmiotów, osób lub działających. Przykładem solidarności subiektywnej byłoby spontaniczne uznanie danej wartości przez podmiot, osobę lub działającego. $Z$ kolei przykładem solidarności intersubiektywnej byłyby solidaryzowanie się z przyjacielem lub z daną grupą, czy też solidarność całej grupy wobec określonych wartości. Wydaje się, że solidarność intersubiektywna jest przykładem zjawiska społecznego w pełnym tego słowa znaczeniu i polega na budowaniu więzi międzyludzkich poprzez tworzenie grup, spontanicznych lub zorganizowanych.

Głównym celem tego artykułu jest próba analizy solidarności właśnie jako zjawiska społecznego. Przyjmuję przy tym przesłankę prima facie, że - jak każde zjawisko - solidarność przedstawia się jako posiadające pewien sens. Proponuję zatem ująć solidarność jako fenomen i zastosować metodę odpowiednią dla analizy tego typu przedmiotów, czyli fenomenologię. Bądź co bądź fenomenologia daje możliwość badania solidarności jako solidarności, to znaczy: ze względu na nią samą, a więc bez przyjmowania z góry zewnętrznych ram teoretycznych, czy to socjologii, historii idei, czy też politologii. Innymi słowy, fenomenologia pozwala na pytanie o istotę solidarności, czyli o ukonstytuowany sens tego zjawiska. Biorąc jednak pod uwagę fakt, że w filozofii przyjęło się badać solidarność jako problem 
filozofii społecznej ${ }^{1}$, na wstępie należy rozważyć istotne zastrzeżenie, które można w tym kontekście sformułować. Skoro bowiem solidarność jest fenomenem społecznym, zaskakiwać może wybór aparatu metodologicznego fenomenologii, którą zwykle wiąże się raczej ze stanowiskiem skrajnie kartezjańskim, a przez to i subiektywistycznym, które wydaje się prowadzić do solipsyzmu. Bez wątpienia, Husserl - twórca fenomenologii - nie jest tutaj bez winy, ponieważ rzeczywiście definiuje on swoją filozofię jako formę „neokartezjanizmu", który dokonuje redukcji primordialnej, wyłączającej wszystko, co nie jest „moje”, a więc i intersubiektywność, poza nawias wiedzy pewnej². W kontrze do tej utartej interpretacji filozofii Husserla jako solipsyzmu, uważam jednak, że zarzut jakoby fenomenologia zamykała się w sferze immanencji i dlatego nie pozwalała na analizę fenomenów społecznych, opiera się na opacznym rozumieniu metody fenomenologicznej. Już chociażby to, że „wyłączenie” w redukcji nie oznacza „eliminacji”, lecz „odkrycie”, pozwala na ograniczenie zakresu obowiązywania przedstawionego zarzutu i na pogłębienie rozumienia fenomenologii jako „neokartezjanizmu”. Nie to jednak jest decydujące.

Nie ulega wątpliwości, że temat intersubiektywności chyba od początków fenomenologii był dla niej problemem. Jak zaznaczono, jej subiektywizm wydawał się prowadzić do solipsyzmu, ponieważ, jak dowodzi Bukowski, „Prawdziwie, rzeczywiście, w oryginale poznawać może tylko Ja transcendentalne, konstytuujące w ten sposób całą pozostałą rzeczywistość. Drugi człowiek pozostał na przeciwległym brzegu, nie sposób do niego dotrzeć inaczej jak do całkowicie zależnego od mej świadomości przedmiotu. Triumf cogito okazał

1 W sprawie ujęcia solidarności w filozofii społecznej, zob. D. Dobrzański, Zasada solidarności. Studium z filozofii społecznej, Poznań 2013.

2 Zob. E. Husserl, Medytacje kartezjańskie z dodaniem uwag krytycznych Romana Ingardena, przeł. i przypisami opatrzył A. Wajs, przekład przejrzał i wstępem poprzedził A. Półtawski, Warszawa 1982, 1, 177. 
się zupełny”3. Sam Husserl mówi o solipsyzmie jako o „najbardziej przykrym nieporozumieniu"4, ponieważ, jak wielokrotnie podkreślał, „Solipsyzm, który mówi: Ja, duchowa istota, jestem sam, wszystko inne jest prostym fenomenem - jest bezsensowny" Intensywne i pogłębione badania nad fenomenologią, które trwają od kilku de$\mathrm{kad}^{6}$, pokazują, że w filozofii tej problem solipsyzmu rzeczywiście nie występuje; nawet więcej, bo Husserl sformułował złożoną teorię intersubiektywności, pokazując koniec końców, że nie ma subiektywności bez intersubiektywności. Jeżeli tak, jakie drogi pozostają wówczas dla fenomenologii solidarności? Bez wątpienia fenomenologia umożliwia opis subiektywnego, czyli pierwszoosobowego doświadczenia solidarności jako aktu solidaryzowania się. W tym jednak się nie wyczerpuje. Jak już podkreślono, solidarność jest pewnym fenomenem. Jako taki, można go ująć z dwóch perspektyw: (a) stosując metody analizy statycznej, można opisać elementy struktury solidarności jako pewnego sensownego zjawiska, zaś (b) stosując

3 J. Bukowski, Zarys filozofii spotkania, Kraków 1987, 68. Zob. także tenże, Próba pogodzenia intersubiektywności z idealizmem transcendentalnym u Edmunda Husserla, Studia Filozoficzne 2(1984)219, 101-114.

4 E. Husserl, Fenomenologia i antropologia, Archiwum Historii Filozofii i Myśli Społecznej (1987)32, 345.

5 E. Husserl, Erste Philosophie (1923/24). Zweiter Teil. Theorie der phänomenologischen Reduktion, red. R. Boehm, Den Haag 1958, 496. W sprawie krytyki solipsyzmu przez Husserl zob. także tenże, Zur Phänomenologie der Intersubjektivität. Texte aus dem Nachlass. Dritter Teil: 1929-1935, red. I. Kern, Den Haag 1973, 3, 12, 61, 401; tenże, Posłowie do moich „Idei czystej fenomenologii ifenomenologicznej filozofii”, tłum. z niem. J. Szewczyk, w: Drogi współczesnej filozofii, wybrał i wstępem opatrzył M.J. Siemek, Warszawa 1978, 65-66.

6 Zob. np. J.R. Mensch, Intersubjectivity and Transcendental Idealism, New York 1988; S. Judycki, Intersubiektywność i czas. Przyczynek do dyskusji nad późna fazą poglądów Edmunda Husserla, Lublin 1990; G. Römpp, Husserls Phänomenologie der Intersubjektivität. Und ihre Bedeutung für eine Theorie intersubjektiver Objektivität und die Konzeption einer phänomenologischen Philosophie, Dordrecht, Boston, London 1992; D. Zahavi, Husserl und die transzendentale Intersubjektivität. Eine Antwort auf die sprachpragmatische Kritik, Dordrecht, Boston, London 1996; W. Płotka, Studia z fenomenologii poznania. Transcendentalna filozofia Edmunda Husserla a problem wiedzy, Gdańsk 2015, 218-229. 
metody analizy genetycznej, można opisać proces solidaryzacji jako konstytuowanie sie grup 7 . W tym artykule odnoszę się do obu tych perspektyw badawczych, pytając (w analizie statycznej) o elementy aktu solidaryzacji oraz (w analizie genetycznej) o konstytuowanie się grup. Co warto podkreślić, zaproponowana perspektywa badawcza, a więc sformułowanie zarysu fenomenologii solidarności jako zjawiska społecznego w świetle pytania o konstytuowanie się grup, przy wykorzystaniu metod analizy statycznej i genetycznej jest oryginalną propozycją teoretyczną, dotychczas nieobecną w literaturze przedmiotu. Na końcu dodam, że dokonując pierwszych ustaleń terminologicznych, należy także odróżnić solidarność od Solidarności, którą można rozumieć jako ruch społeczno-robotniczy, który na początku lat 80 . XX wieku znalazł instytucjonalną reprezentację w postaci NSZZ Solidarność. W artykule tym nie interesuję się ani historycznymi związkami fenomenologii z NSZZ Solidarnościq ${ }^{8}$, ani fenomenologią Solidarności $i^{9}$.

Prezentując zarys fenomenologii solidarności, w pierwszej kolejności sięgnę do polskiej literatury filozoficznej, rekonstruując i krytycznie opracowując rozumienie solidaryzacji przez Ingardena i Tischnera. Obaj filozofowie wychodzą od opisów solidaryzacji subiektywnej, przy czym ten drugi - w ramach późniejszej koncepcji etyki solidarności - przeformułowuje ją w teorię solidaryzacji intersubiektywnej. Niemniej jednak, jak będę starał się dowieść, fenomenologia, która sprowadza solidaryzację do immanentnego doświadczenia nie jest w stanie przekonująco pokazać procesu konstytucji grupy.

7 Problem analizy statycznej i genetycznej badam szerzej w: Analiza struktury i geneza egzystencji: dwie postacie metody fenomenologicznej, Kwartalnik Filozoficzny 40(2012)3, 23-41.

8 Zob. M. Gubser, The Far Reaches. Phenomenology, Ethics, and Social Renewal in Central Europe, Stanford 2014, 196-216.

9 W sprawie filozoficznej analizy ruchu Solidarności, jego kontekstu historycznego i późniejszego rozwoju, zob. T. Buksiński, Od etyki solidarności do etycznego egoizmu, Filo-Sofija 29(2015)2, 37-57 oraz C. Taylor, Kilka uwag na temat solidarności, Znak 52(2000)8, 22-34. 
Paradoksalnym rozwiązaniem byłoby zajęcie pozycji idealizmu, co jednak Ingarden i Tischner odrzucali. Problem przejścia od solidaryzacji subiektywnej do intersubiektywnej zdefiniuję jako problem mostu. W kolejnej części artykułu postaram się przedstawić alternatywną propozycję fenomenologii solidarności, która, sięgając do metod analizy statycznej i genetycznej, pyta o struktury solidaryzacji i proces konstytuowania się grup. Podejmę przy tym pytanie o możliwość eksplikacji teorii intencjonalności kolektywnej w oparciu o pisma Husserla i przedstawię elementy aktu solidaryzowania się jako aktu konstytucji grup zorientowanych na realizację określonego celu. Ostatecznie ujmę solidarność jako sposób odniesienia do świata jako świata wspólnego, rozumianego w modi „my”, wobec którego jest się współodpowiedzialnym.

\section{OD SOLIDARYZACJI EGOTYCZNEJ DO SPOŁECZNEJ: PROBLEM MOSTU}

Analizy solidaryzacji10 ${ }^{10}$ zostają podjęte przez Ingardena i Tischnera na tle ich rozważań ontologiczno-aksjologicznych i ogniskują się na zagadnieniu egotycznego wymiaru tego aktu. Jest to o tyle zrozumiałe, o ile weźmie się pod uwagę fakt, że fenomenologia w ogóle dotyczy aktowo ujętego doświadczenia. Wyróżniając jednak ten aspekt solidaryzacji, powstaje problem opisu solidaryzacji intersubiektywnej: w jaki sposób, jeżeli w ogóle, podmiot jest w stanie dokonać aktu solidaryzacji intersubiektywnej? Czy warunkiem tego aktu jest przyjęcie określonej apriorycznej struktury, która go umożliwia? Czy uzasadnione jest zatem przejście od solidaryzacji subiektywnej do intersubiektywnej? Koniec końców pytania te dotyczą problemu mostu, czyli fenomenologicznego opisu zjawisk społecznych w ogóle i zjawiska solidarności w szczególności. Biorąc pod uwagę egotyczny charakter analiz Ingardena lub późniejszą koncepcję etyki solidarności

10 W tym, jak i w dalszych częściach artykułu, wyrażenia „solidaryzacja”, którym posługują się Ingarden i Tischner, używam w znaczeniu „akt solidaryzowania się”. 
Tischnera, w której solidarność ujmuje się jako „solidarność sumień”, problem ten jest istotnym problemem fenomenologii solidarności. W tej części artykułu bliżej się jemu przyjrzę.

Filozofia praktyczna Ingardena, w ramach której prezentuje on analizę fenomenu solidaryzacji egotycznej, łączy w sobie - na co wskazuje Gołaszewska ${ }^{11}$ - rozstrzygnięcia z dziedziny ontologii (status istnienia wartości), teorii poznania (dyskusja z relatywizmem) oraz z antropologii filozoficznej (rozumienie człowieka jako systemu względnie izolowanego). Ujmując tę filozofię możliwie szeroko, należy zaznaczyć, że Ingarden nie rozstrzyga problemu istnienia wartości12 i przyjmuje, że są one realizowane w świecie przez podmiot odpowiedzialny za ich urzeczywistnienie. U podstaw realizacji jest więc doświadczenie aksjologiczne, które, jak każde doświadczenie, ma intencjonalną strukturę przedmiotowo-podmiotową: (a) od strony przedmiotowej wartości „domagają się" urzeczywistnienia, ponieważ wartość „powinna” istnieć13 ${ }^{13}$ z kolei (b) od strony podmiotowej mówi się o przeżywaniu wartości w formie emocjonalnej na nie reakcji1".

11 Zob. M. Gołaszewska, Romana Ingardena filozofia moralności, Etyka (1971)9, 113-114.

12 „Wartości nie są ani w tym sensie realne, w jakim realny jest prąd elektryczny przepływający przez drut, ani w tym sensie realne jak realny jest np. gniew ludzki lub zachwyt, ale też wcale nie są tylko intencjonalnymi odpowiednikami naszych uczuć, pożądań, pomyśleń czy ocen. Trzeba by tu szukać jakiejś pośredniej, jakiegoś odmiennego modus existentiae, który z jednej strony, byłby czymś mniej, czymś innym niż prosta realność, a z drugiej strony byłby czymś więcej i innym niż prosta intencjonalność, zwykły koszmar ludzki narzucany na świat z powodu ludzkiego błędu czy takich lub innych uczuć". R. Ingarden, Wykłady z etyki, wybrał, opracował i wstępem poprzedził A. Węgrzecki, Warszawa 1989, 337.

13 Syntetyczne przedstawienie przedmiotowego aspektu tego aktu znajduje się w: A. Węgrzecki, Podmiotowość i wartości, w: Roman Ingarden a filozofia naszego czasu, red. A. Węgrzecki, Kraków 1995, 155-156.

14 „Nie ma też Ingarden wątpliwości, że w całym obcowaniu z wartościami zarówno estetycznymi jak innymi, obejmującym poznawcze uchwycenie oraz aprobującą lub dezaprobującą odpowiedź, istotna rola przypada emocjom". A. Węgrzecki, O doświadczeniu aksjologicznym, w: W kręgu filozofii Romana Ingardena. Materiały z konferencji naukowej Kraków 1985, red. W. Stróżewski, A. Węgrzecki, Warszawa, Kraków 1995, 165. 
Ingarden opisuje fenomen solidaryzacji lub desolidaryzacji w kontekście podmiotowej reakcji na wartości jako reakcji emocjonalnej. Pisze on mianowicie o „odruchowej”, „wyraźnie nieuświadomionej” i „nieprzemyślanej” relacji do tego, co się właśnie żywi ${ }^{15}$, precyzując, że relacja ta ma charakter "mimowolnego" i „uczuciowego" poczucia akceptacji lub odrzucenia ${ }^{16}$. Co ważne, solidaryzowanie się lub niesolidaryzowanie się z określonymi uczuciami pokazuje, że reakcja podmiotu moralnego jest dobra lub zła, a przez to może on sobie zdać sprawę, że jest odpowiedzialny za to, co robi.

Pozostawiając na boku kwestie ontycznych podstaw odpowiedzialności ${ }^{17}$, widać, że dla Ingardena solidaryzacja egotyczna określa emocjonalną reakcję na wartości, zobowiązując podmiot moralny do określonego działania. $Z$ kolei gdy odpowiedzialność nie ma charakteru jedynie egotycznego, lecz dotyczy pewnej społeczności, ma ono formę wspótodpowiedzialności, jak opisuje to filozof, „(...) za to, co się w niej [społeczności] dzieje”, i dodaje: „(...) na mnie ciąży obowiązek jakiegoś działania, chociaż nie ja coś czynię”, po czym dodaje: „Jest to zagadnienie solidarności, solidarności z pewną grupą społeczną, czasem solidarności z przyjacielem. Dopiero ta solidarność, to poczucie solidarności, stwarza podstawę do współodpowiedzialności za to, co się dzieje w tym gronie, z którym czuję się solidarny" ${ }^{18}$. A więc jest to solidarność intersubiektywna, która różni się od wcześniej opisanej przynajmniej w dwóch aspektach: (a) jest relacją do grupy lub innego podmiotu oraz (b) jest korelatem wspótodpowiedzialności, która w pewnym sensie ogranicza pole wolności podmiotu moralnego

15 Zob. R. Ingarden, dz. cyt., 217.

16 Zob. tamże, 218.

17 Zob. w szczególności R. Ingarden, O odpowiedzialności i jej podstawach ontycznych, w: tenże, Ksiq̨żeczka o człowieku, Kraków 1998, 71-169. Zaś w sprawie dyskusji nad propozycją Ingardena, zob. J.J. Jadacki, Odpowiedzialność i istnienie świata, Studia Filozoficzne 5(1973)90, 245-257 oraz W. Stróżewski, Nad „Książeczką o człowieku”, Studia Filozoficzne 9(1973)94, 123-126.

18 R. Ingarden, Wykłady z etyki, 247. 
(„nie ja to czynię”). Co jest szczególnie interesujące, Ingarden nie poprzestaje na opisie różnych form solidarności, lecz pyta także o ich związki. I tak, dowodzi, że "Jeżeli solidarność z kimś wynika [podkr. - W.P.] z własnych interesów, jeżeli jest ona tylko postacią samoobrony, a nie wynika z poczucia [podkr. - W.P.] posiadania pewnych obowiązków w stosunku do ludzi, którym jest się wiernym, to takie postępowanie od razu traci na wartości z punktu widzenia moralnego" 19 . Przytoczony fragment jest ważny z dwóch powodów: (a) świadczy on o redukcji solidarności społecznej do egotycznej, bo o jej znaczeniu decyduje subiektywne poczucie lub jego brak; oraz (b) pokazuje, że analiza solidarności jako fenomenu społecznego wydaje się przekraczać ramy fenomenologii, gdyż można wątpić, czy pytanie o to, skąd wynika solidarność intersubiektywna na pewno jest problemem, który można rozstrzygnąć na gruncie fenomenologii. Uważam, że pierwszy z zarysowanych tutaj problemów pokazuje niemożliwość ujęcia solidarności jako zjawiska w istocie społecznego, bo redukuje się je do pierwszoosobowych doświadczeń. Dlaczego bowiem istotą solidarności intersubiektywnej ma być egotyczne odczucie, nie zaś jego przekroczenie („nie ja coś czynię”)? Drugi zaś problem świadczy o trudnościach w powiązaniu obu form solidarności. Stąd, że czuje ciążący na mnie obowiązek, nie wynika, że jestem wspótodpowiedzialny.

Węgrzecki, zarysowując różnice w podejściu Ingardena i Tischnera, uważa, że o ile dla tego pierwszego świadomość egotyczna jest pierwotna, dla tego drugiego ego konstytuuje się wraz z solidaryzowaniem się ${ }^{20}$. Nie ulega wątpliwości, że pojęcie solidaryzacji jest jednym z centralnych we wczesnym okresie twórczości autora Filozofii dramatu. Opisany w Impresjach aksjologicznych ${ }^{21}$ i w rozprawie

19 Tamże, 321.

20 Zob. A. Węgrzecki, Tischner i Ingarden, Kwartalnik Filozoficzny 35(2007)1, 85.

21 Zob. J. Tischner, Impresje aksjologiczne, w: tenże, Świat ludzkiej nadziei, Kraków 2005, 151-153. 
habilitacyjnej22, fenomen solidaryzacji (i desolidaryzacji) egotycznej lub egologicznej dotyczy konstytucji ego przez „zwiększanie lub zmniejszanie obszaru swojej rzeczywistości"23. Obszar egotyczny jest równy z tym, co „moje”, przy czym „Solidaryzacja ma charakter ontologiczny" 24 , co oznacza, że w jej rezultacie ego ujmuje przedmiot solidaryzacji jako siebie, czyli w ogóle istnieje jako to, z czym się solidaryzuje. Tischner nazywa ten proces „wewnętrzną solidaryzacją”, dowodząc, że solidaryzacja dokonuje się w horyzoncie wartości. Stąd jednak, że wartości są transcendentne, Tischner wnosi, że także podmiot aktu solidaryzacji jest transcendentny ${ }^{25}$. Galarowicz, dyskutując nad tą propozycją, słusznie zauważa, że prowadzi ona do dualizmu, ponieważ „Człowiek (ja aksjologiczne) ma wymiar transcendentny (transcendentalny) i realny, światowy: żyjąc w tym świecie, nie jest $\mathrm{z}$ tego świata"26. W Impresjach aksjologicznych autor wyprowadzał $\mathrm{z}$ tego dualizmu właściwy człowiekowi dramat: ponieważ Ja aksjologiczne jest transcendentne, nie może się spełnić ${ }^{27}$. Niezależnie od tego, trzeba zauważyć, że zarzut ten pośrednio dotyczy także problemu mostu, bo solidaryzacja odbywa się w sferze monadycznej i irrealnej; jako taka nie może mieć charakteru ani intermonadycznego, ani realnego, przez co wyklucza możliwość opisu solidaryzacji intersubiektywnej.

Wydawać by się mogło, że późniejsza koncepcja etyki solidarności przekracza ograniczenia wczesnej teorii ja aksjologicznego. Bądź co bądź Tischner przyjmuje, że solidarność jest zjawiskiem społecznym,

22 Zob. J. Tischner, Fenomenologia świadomości egotycznej, w: tenże, Studia z filozofii świadomości, opracował naukowo i przedmową opatrzył A. Węgrzecki, Kraków 2006, 220-228.

23 Zob. J. Tischner, Impresje aksjologiczne, dz. cyt., 152.

24 J. Tischner, Fenomenologia świadomości egotycznej, dz. cyt., 228.

25 O sposobie istnienie Ja aksjologicznego, zob. J. Tischner, Impresje aksjologiczne, dz. cyt., 162, przypis.

26 J. Galarowicz, Paradoks egzystencji etycznej. Inspiracje: Ingarden - Wojtyła - Tischner, Kraków 2009, 299.

27 Zob. J. Tischner, Impresje aksjologiczne, dz. cyt., 164. 
ponieważ „(..) jest solidarnością z ludźmi i dla ludzi”28. Jako taka realizuje się wobec krzywdy innej osoby (lub osób), co świadczy o jej moralnym charakterze. Dlatego solidarność ma być przede wszystkim zagadnieniem etycznym. W jaki sposób konstytuuje się tak rozumiana solidarność społeczna? Odpowiedź na to pytanie wymaga zdania sobie sprawy, że dla Tischnera (a) solidarność jest sprawą sumienia, które rozumie jako (b) naturalny „zmysł etyczny”, doświadczany jako $(c)$ spontaniczne i $(d)$ nieomylne $(e)$ wezwanie do podjęcia określonego działania. Według filozofa, „Autentyczna solidarność (...) jest solidarnością sumień. To zrozumiałe, bo być solidarnym z człowiekiem to zawsze móc liczyć na człowieka, a liczyć na człowieka to wierzyć, że jest w nim coś stałego, co nie zawodzi. Sumienie jest w człowieku tym, co stałe i co nie sprawia zawodu" 29 . Powiązanie solidarności z sumieniem jest zatem uzasadnione jako próba opisania tworzenia się wspólnoty, czy też grupy. Chociaż sumienie, jak przyznaje Tischner, można stracić, jest ono koniec końców tym, co uprawomocnia i stwarza wspólnotę. To przecież naturalnego „zmysłu etycznego” doświadcza się jako „wewnętrznego głosu”, który można opisać jako spontaniczne uznanie lub odrzucenie określonej wartości lub grupy wartości, co buduje więź między jednym i drugim podmiotem. Rację wydaje się zatem mieć Światała, który podkreśla, że „Zjawisko solidarności, jakie pojawia się w relacjach międzyludzkich, to (...) bezpośredni efekt wrażliwości sumienia, spontaniczny odruch na ludzką krzywdę owocujący chęcią niesienia pomocy" ${ }^{30}$. Jeżeli jednak przyjmie się tego typu konstrukcję, w pełni zauważalny jest problem mostu, który u Tischnera przybiera formę

28 J. Tischner, Etyka solidarności, w: tenże, Etyka solidarności oraz Homo sovieticus, Kraków 2005, 18.

29 Tamże.

30 I.M. Światała, Ks. Józef Tischner: Etyka solidarności, czyli chrześcijański model rzeczywistości społecznej i politycznej, w: Etyka solidarności. W 10. rocznicę śmierci ks. Józefa Tischnera, red. W. Słomski, Warszawa 2010, 94. 
pytania: „Czy pierwsze jest »my«, czy pierwsze jest »dla niego«?”31. Zdaniem filozofa, „Wspólnota solidarności różni się od wielu innych wspólnot tym, że w niej pierwsze jest »dla niego«, a »my« przychodzi potem. Najpierw jest ranny i jego krzyk. Potem odzywa się sumienie, które potrafi słyszeć i rozumieć ten krzyk. Dopiero stąd rośnie wspólnota" 32 .

Rozwiązanie Tischnera nie jest jednak przekonujące z co najmniej trzech powodów: (a) nie jest do końca jasne, co oznaczają w tym kontekście terminy „pierwszy” i „potem”; niezależnie od tego, (b) przedstawiony opis zakłada wspólnotę, ale go nie wyjaśnia; oraz (c) popada w błędne koło. I tak, filozof może się tutaj odnosić do porządku $\left(a_{1}\right)$ czasowego, $\left(a_{2}\right)$ ontologicznego, $\left(a_{3}\right)$ logicznego lub $\left(a_{4}\right)$ transcendentalnego (porządku konstytucji). Biorąc pod uwagę kontekst, wydaje się, że mowa jest tutaj o porządku czasowym. Jeżeli tak, wówczas nie jest jasne, w jaki sposób „stąd rośnie wspólnota”, czyli jak następuje przejście od „dla niego”, czyli od „spontanicznego odruchu” i troski do „my”, czyli już ukonstytuowanej wspólnoty. Problem mostu dotyczy zatem przejścia od momentu $t_{1}$, gdy ma się do czynienia $z$ indywidualnym „odruchem”, do momentu $t_{2}$, gdy dana jest już wspólnota. Z tego powodu, wspólnotę co najwyżej się zakłada, lecz się jej nie wyjaśnia. Co więcej, jeżeli solidarność - jak deklaruje Tischner w pierwszym rozdziale Etyki solidarności ${ }^{33}$ - jest rzeczywiście solidarnością sumień, a solidarność zakłada wspólność doświadczenia, wówczas wspólnotę zakłada się już w pierwszym kroku, aby móc ją wyprowadzić w drugim kroku. Stąd błędne koło: wspólnota konstytuuje się, ponieważ podmiot ma określone doświadczenie, ale to doświadczenie jest możliwe, ponieważ podmiot uczestniczy we wspólnocie.

31 J. Tischner, Etyka solidarności, 20.

32 Tamże.

33 Zob. tamże, 15. 


\section{ELEMENTY STRUKTURY AKTU SOLIDARYZOWANIA SIĘ JAKO AKTU ZŁOŻONEGO}

Zarówno Ingarden, jak i Tischner w swoich analizach solidarności - wychodząc od solidarności subiektywnej i pytając o przejście do solidarności intersubiektywnej - nie potrafili, jak przedstawiono powyżej, rozwiązać problemu mostu. Pewnym rozstrzygnięciem byłoby zajęcie stanowiska idealizmu absolutnego, ponieważ wówczas podmiot bytby wspólnotą, która zawierałaby w sobie podmioty jako części wspólnoty. Stanowisko to jednak - zbliżone do pozycji Hegla - obaj myśliciele słusznie odrzucają ${ }^{34}$. Nie pozwala ono także, jak się wydaje, na wyprowadzenie istotnych tez na temat solidarności. W tej części artykułu proponuję inną drogę ominięcia problemu mostu i przyjmuję, że zarówno Ingarden, jak Tischner zbyt pospiesznie uznają, że próba wyprowadzenia solidarności intersubiektywnej z subiektywnej jest w ogóle konieczna dla jej zrozumienia. Dlatego chciałbym pokazać, że Tischner zbyt pochopnie przeciwstawia sobie „dla niego” i „my”, nie dostrzegając, że są to dwie formy jednego doświadczenia. To, co się zmienia to sposób odnoszenia się podmiotu do świata, nie ma zaś mowy o odrębnym doświadczeniu ${ }^{35}$. Dlatego zamiast pytać o subiektywne warunki solidarności jako zjawiska społecznego, chciałbym tutaj opisać strukturę i elementy aktu solidaryzowania się, sięgając przy tym do narzędzi analizy statycznej w fenomenologii Husserla.

34 Dyskusję z heglowskim rozwiązaniem problemu mostu, które przyjmuje istnienie podmiotów wspólnych i świadomości kolektywnej, wyjaśnia co najwyżej to, że społeczność jest warunkiem rozumienia siebie jako świadomego podmiotu, a przez to dotyczy teorii poznania, nie zaś społecznej konstytucji grup. Na ten temat, zob. E. Chelstrom, Social Phenomenology. Husserl, Intersubjective, and Collective Intentionality, Lanham, Boulder, New York, Toronto, Plymouth 2013, 60-61.

35 W tę stronę, chociaż nie tyle w odniesieniu do tematu solidarności, co raczej do wspólnoty w ogóle, idzie w swojej argumentacji Caminada. Zob. E. Caminada, Husserl on Groupings: Social Ontology and the Phenomenology of We-Intentionality, w: Phenomenology of Sociality: Discovering the 'We', red. T. Szanto, D. Moran, New York 2016, 292. 
Akt solidaryzowania się jest aktem złożonym, co oznacza, że jest aktem ufundowanym na innych aktach i dlatego należy go opisać w słowniku mereologicznym części i całości ${ }^{36}$. Opis ten dotyczy całości aktu solidaryzowania się, który łączy w sobie akty (a) poznawcze, (b) wolitywne i (c) afektywne (emocjonalne), przy czym, jak sądzę, solidaryzując się podmiot przede wszystkim chce podjąć określone działania, ponieważ odczuwa określone emocje. Wydaje się zatem, że treść propozycjonalna aktu działania, dajmy na to, uzasadnienie tego, że dany podmiot solidaryzuje się z innym, towarzyszy w solidaryzacji spontanicznemu uznaniu pewnych wartości i ich współodczuwaniu. Niezależnie od tego, akt wolitywny, który składa się na złożony akt solidaryzacji, może także przybierać formę ograniczenia działania podmiotu ze względu na wspólnie realizowany cel, to znaczy, wspólnota może realizować cel, którego realizacji podmiot może nie chcieć. To jednak, że podmiot jest współodpowiedzialny za innych, sprawia, że musi on zawiesić, czy raczej przekroczyć indywidualne preferencje na rzecz wspólnoty. Przed pogłębieniem tego opisu podmiotowego aspektu aktu, należy zauważyć, że od strony przedmiotu, akt ten - jako akt społeczny - ma bliższy i dalszy przedmiot. Bliższym przedmiotem tego aktu jest inny podmiot (np. solidaryzacja z przyjacielem) lub grupa podmiotów (np. solidaryzacja z powodzianami). Dalszym zaś są wartości, ze względu na które podmiot się solidaryzuje z innym podmiotem. Właśnie ze względu na skierowanie na wartości, akt solidaryzacji jest złożony także $\mathrm{z}$ aktu emocjonalnego, który służy wypełnieniu

36 W sprawie rozumienia aktu złożonego przez Husserla, zob. E. Husserl, Badania logiczne. Tom II. Badania dotyczące fenomenologii i teorii poznania. Część I, przeł., wstępem poprzedził i przypisami opatrzył J. Sidorek, przekład przejrzał A. Półtawski, Warszawa 2000, 277-283. W odniesieniu do Husserla teorii całości i części, zob. M. Rosiak, Z problematyki ontologii formalnej: Fenomenologiczne teorie całości i części, w: Wprowadzenie do fenomenologii. Interpretacje, zastosowania, problemy. T. II, red. W. Płotka, Warszawa 2014, 377-409 oraz R. Sokolowski, The Logic of Parts and Wholes in Husserl's Investigations, Philosophy and Phenomenological Research 4(1968)28, 537-553. 
tej intencji ${ }^{37}$. Z kolei obecność aktu wolitywnego dotyczy wspólnego działania. Jeżeli brakuje tego elementu, zaś akt kieruje się ku innemu podmiotowi (lub podmiotom), realizując się $\mathrm{w}$ formie odpowiedniego uczucia (np. współczucie ofiarom wypadku), wówczas ma się do czynienia $\mathrm{z}$ aktem empatii, fundującym - jak pokazuje to Szanto ${ }^{38}$ - inne, bardziej złożone formy i poziomy konstytucji aktów społecznych.

Opisując strukturę aktu solidaryzowania się, należy także wskazać na (a) jego wyobrażeniową treść, (b) protencjonalny horyzont czasowy oraz $(c)$ aspekt normatywny. I tak, po pierwsze, treść tego aktu odnosi do przedmiotu, bliższego i dalszego, w charakterze treści wyobrażeniowej. Rzecz w tym, że treść ta nie prezentuje swoich przedmiotów, jak ujmuje to Husserl w Ideach I, w charakterze ,istnienia” (vorbanden) i „bycia rzeczywistym” 39 . Oznacza to, że aktowi solidaryzacji brakuje momentu tetycznego, co jest równoznaczne z ujęciem przedmiotu w „modyfikacji neutralnościowej” 40 , w której jedynie coś sobie można uprzytomnić, ale „bez uznania tego w bycie”. Moment ten jest istotny dla zrozumienia, że solidaryzując się podmiot wyobraża sobie, dajmy na to, odczucia innego podmiotu lub w przypadku działań wspólnotowych, jakie skutki tego typu działania mogłyby przynieść. Dlatego, po drugie, równie ważne jest wskazanie, że ze względu na strukturę czasową, podmiot przeżywa przede wszystkim moment protencjonalny, a więc przyszłościowy. Idzie o podkreślenie zorientowania podmiotu na to, co będzie, jak na przykład w solidaryzacji z powodzianami, grupa solidaryzuje się,

37 „Der intellektiven Erfüllung läuft parallel die emotionale. Das Werten ist nicht nur richtig, sondern vollkommen begründet, und diese Begründung besagt nicht Begründung durch das Denken, sondern Gemütsbegründung". E. Husserl, Vorlesungen über Ethik und Wertlehre. 1908-1914, red. U. Melle, Dordrecht, Boston, London 1988, 241.

38 Zob. T. Szanto, Husserl on Collective Intentionality, w: The Phenomenological Approach to Social Reality, red. A. Salice, H.B. Schmid, Dordrecht 2016, 150.

39 E. Husserl, Idee czystej fenomenologii i fenomenologicznej filozofii, przeł. i przypisami opatrzyła D. Gierulanka, tłumaczenie przejrzał i wstępem poprzedził R. Ingarden, Warszawa 1967, 162.

40 Zob. tamże, 374. 
aby zapewnić bezpieczeństwo lub pomóc. Innymi słowy, wspólnota ukonstytuowana w akcie solidaryzowania się jest wspólnotą działającą ze względu na cel ${ }^{41}$. W końcu, po trzecie, istotnym elementem aktu solidaryzowania się jest aspekt normatywny, przez co należy rozumieć nie tylko powinnościowy charakter istnienia wartości (dalszego przedmiotu), ze względu na które podmiot się solidaryzuje, ale i odpowiedzialność za inny podmiot lub podmioty. Dla Husserla odpowiedzialność ma już zawsze charakter współodpowiedzialności, konstytuującej się wspólnotowo ${ }^{42}$.

Powracając do pytania o podmiotową stronę aktu solidaryzacji, nasuwa się pytanie o to, jak należy rozumieć w tym kontekście podmiot. Jest to pytanie o tyle istotne, o ile ma się na uwadze propozycję Husserla ujęcia podmiotu społecznego jako „wspólnego ducha” (Gemeingeist $)^{43}$. Opis taki - przy interpretacji zaproponowanej przez Schutza ${ }^{44}$ - może sugerować mianowicie, że solidarność jako zjawisko społeczne ma właściwy sobie podmiot ogólny, różny od podmiotów indywidualnych, który posiada odpowiednie własności, jak przekonania, chcenia, działania lub emocje. Wbrew jednak temu, jak przekonująco argumentuje Szanto ${ }^{45}$, opis ten nie zakłada istnienia specjalnych własności przeżyciowych „wspólnej świadomości”, lecz wskazuje na istotowo intersubiektywny charakter podmiotu. Dla Husserla bowiem subiektywność konstytuująca się we wspólnocie

41 Na marginesie można dodać, że ten aspekt aktu solidaryzowania się widać wyraźnie w przypadku działań wspólnotowych, jakimi są strajki, podejmowane przecież przez daną grupę dla realizacji określonych celów.

42 „Aber Selbstverantwortung ist für den Menschen, der Mensch ist im gemeinschaftlichen Sein und vergemeinschafteten Leben, eins mit der Verantwortung vor Anderen und mit dem Verantwortlichmachen der Anderen”. E. Husserl, Zur Phänomenologie der Intersubjektivität Texte aus dem Nachlass. Dritter Teil: 1929-1935, dz. cyt., 422.

43 Zob. E. Husserl, Zur Phänomenologie der Intersubjektivität. Texte aus dem Nachlass. Zweiter Teil: 1921-1928, red. I. Kern, Den Haag 1973, 165-184, 192-204.

44 Zob. A. Schutz, Das Problem der transzendentalen Intersubjektivität bei Husserl, Philosophische Rundschau 5(1957), 81-107.

45 Zob. T. Szanto, dz. cyt., 165. 
jest ze swej istoty odniesiona do innego podmiotu, co oznacza, że ma formę ego-alteri ${ }^{46}$. Nie jest zatem tak, jak u Tischnera, jakoby podmiot uczestniczył we wspólnocie, która konstytuuje się w aktach solidaryzowania się, ponieważ ma określone subiektywne przeżycie. Akt ten zmienia raczej sposób doświadczania świata, a mianowicie doświadczenia świata jako korelatu grupy lub wspólnoty. Biorąc pod uwagę złożoną strukturę tego aktu, można teraz zapytać o to, w jaki sposób w akcie solidaryzacji konstytuuje się grupa.

\section{GENETYCZNE UJĘCIE SOLIDARNOŚCI: JAK KONSTYTUUJE SIĘ GRUPA?}

Zarówno Chelstrom, jak i Caminada podkreślają, że pełniejszemu zrozumieniu zjawisk społecznych $\mathrm{w}$ fenomenologii Husserla służy metoda genetyczna ${ }^{47}$. Dzieje się tak z dwóch powodów: (a) uwzględnia ona opis doświadczenia jako horyzontalnego, co oznacza, że podmiot zawsze jest już osadzony w określonym społecznie, kulturowo i historycznie kontekście oraz (b) pyta raczej o proces socjalizacji, a nie o struktury uwspólnoconego doświadczenia. Już wcześniej zauważono, że akt solidaryzowania się konstytuuje grupę, która organizuje swoje celowościowe działania ze względu na realizację określonych wartości. Co jednak oznacza, że w akcie solidaryzacji konstytuuje się grupa? W tej części artykułu, próbując odpowiedzieć na to pytanie, dążę do pogłębienia opisu wspólnotowego doświadczania świata $\mathrm{w}$ akcie solidaryzacji, na co wskazywałem już w zarysie w części poprzedniej. Korzystam przy tym $z$ narzędzi analizy genetycznej w fenomenologii Husserla.

46 „Die Gemeinschaftssubjektivität ist eine vielköpfige Subjektivität, Form des ego-alteri. Jedes vergemeinschaftete ego hat nicht nur sein Bewusstsein, sondern seines als in die Anderen hineinschauendes und sich mit den Anderen zu einem universalen Bewusstseinszusammenhang mit vielköpfiger Subjektivität verbindend, aber freilich sich ins Unbestimmte verlierend". E. Husserl, Zur Phänomenologie der Intersubjektivität. Texte aus dem Nachlass. Zweiter Teil: 1921-1928, dz. cyt., 218.

47 Zob. E. Chelstrom, dz. cyt., 109 oraz E. Caminada, dz. cyt., 290. 
Na wstępie można jednak zapytać, co w zasadzie oznacza w tym kontekście pytanie o genezę? Oczywiście nie idzie o rekonstrukcję ciągu przyczynowo-skutkowego, który doprowadził do powstania grupy, lecz raczej o opisanie pasywno-afektywnego doświadczenia jako procesu nadawania sensu. Jak już podkreślono powyżej, grupa, która konstytuuje się w akcie solidaryzacji jest złożoną strukturą, która buduje świadomość lub podmiotowość wyższego rzędu. Według Szanto ${ }^{48}$, u Husserla można wyróżnić cztery poziomy świadomości społecznej: (a) świadomość empatyczną (spontaniczne doświadczenie świadomości innych); (b) świadomość syntetyczną świata (doświadczenie świata jako tego samego dla różnych podmiotów); (c) świadomość społeczną (poczucie przynależności do danej grupy, np. rodziny lub klasy społecznej); oraz (d) świadomość sui generis wyższego rzędu, która realizuje się w pojedynczych aktach. Akt solidaryzowania się byłby aktem wyższego rzędu, przez co powstaje pytanie o pasywno-afektywne doświadczenie, w którym świat ujmuje się w określony sposób. Pytając więc o genezę solidarności, docieka się tego, w jaki sposób solidarność określa doświadczenie świata. Skoro jednak mówi się o poziomie afektywno-pasywnym, genetyczne ujęcie solidarności musi wyjść od korelatywnego rozumienia doświadczenia, gdzie świat wspólnoty doświadcza się zarazem poprzez tworzenie wspólnoty i uspołecznianie podmiotów. A więc, „,...) nie ma pojedynczej osoby bez innego indywiduum oraz ewentualnie bez wspólnoty osób" 49 . Solidarność jest więc szczególnym rodzajem procesu społecznego, który stwarza podmiotowość, zarówno na poziomie indywidualnym, jak i intersubiektywnym, chociaż - pokreślę raz jeszcze - na płaszczyźnie pasywno-afektywnej. Jest to podmiotowość określona przez wspólnotę (stąd pasywność) jako współodpowiedzialna za realizację określonych wartości w konkretnych działaniach; podmiot konstytuuje się w reakcji na wartości wspólnotowe (stąd afektywność).

48 Zob. T. Szanto, 150-151.

49 Tamże, 152. 
Współodpowiedzialność wiąże się tutaj z pasywno-afektywnym zakorzenieniem solidarności: chociaż podmiot aktywnie nie chce czegoś zrobić, powinien on zawiesić swoje subiektywne preferencje i działać na rzecz wspólnoty oraz jej dobra. Husserl nazywa taką wspólnotę wspólnotą woli (Willensgemeinschaf), analizując przy tym fenomen wspólnego działania. Przyjrzyjmy się bliżej tym analizom.

I tak, Husserl opisuje różne, coraz bardziej złożone przypadki wspólnego działania i zobowiązania się do wzajemnego spełnienia życzenia. Na początku, jak pisze: „Spełnię twoje życzenia, gdy ty spełnisz moje, zrobię to, co wyjdzie ci na dobre, gdy ty będziesz działał na moją korzyść”, i dodaje: „Dalej: Życzymy sobie, aby coś się stało, decydujemy się na coś »wspólnie«, przy tym ja zrobię część, a ty inną część" 50 . Ta sytuacja jest bardziej złożona o tyle, że wspólnota nie jest podmiotem odrębnym od jej członków, cel zaś jest wspólny w tym sensie, że podmioty chcą jego realizacji jako celu wspólnego. Husserl opisuje to następująco: " $\mathrm{S}_{1}$ i $\mathrm{S}_{2}$ chcą tego samego $\mathrm{G}$, ale nie każdy dla siebie, lecz $\mathrm{S}_{1}$ chce $\mathrm{G}$ tak, jak $\mathrm{S}_{2}$ chce tego, wola $\mathrm{S}_{2}$ należy do chcenia $\mathrm{S}_{1}$ i odwrotnie" ${ }^{1}$. Komentując ten fragment, Szanto dostrzega tutaj taką koncepcję intencjonalności kolektywnej, w której podkreśla się, że „(...) przez dokładnie tę intencję, poprzez którą jeden podmiot funkcjonalnie uczestniczy, czy raczej realizuje w niej intencjonalną treść innego podmiotu jako wspólnego »oznacza« osiągnięcie współdzielonego celu"52. Co ważne, wspólnota konstytuuje się poprzez działanie nakierowane na cel, lecz nie jako odrębny podmiot. Tym, co tutaj następuje jest zmiana ujęcia celu, do którego dąży podmiot jako celu wspólnego, co oznacza: perspektywa subiektywna staje się perspektywą intersubiektywną, co na poziomie językowym jest skorelowane ze zmianą, dajmy na to, opisywania swojego działania

50 E. Husserl, Zur Phänomenologie der Intersubjektivität. Texte aus dem Nachlass. Zweiter Teil: 1921-1928, dz. cyt., 170.

51 Tamże.

52 T. Szanto, dz. cyt., 159. 
za pomocą wyrażenia: „chcę G” na „chcemy G”. Grupa więc konstytuuje się we wspólnym działaniu, które w akcie solidaryzacji nabiera normatywnego charakteru współodpowiedzialności. Solidarność, mówiąc inaczej, realizuje się dokładnie w tych procesach tworzenia wspólnoty działania.

Biorąc pod uwagę, że solidarność konstytuuje podmioty jako uczestniczące w danej grupie, widać, że pozwala ona doświadczyć świata jako świata wspólnego ${ }^{53}$. Solidarność w perspektywie genetycznej prezentuje się jako proces nadawania sensu światu właśnie jako światu wspólnemu. To, że podmiot solidaryzuje się z daną grupą oznacza więc koniec końców, że świat, w którym oni żyją jest ujęty jako „nasz” świat. Dlatego podmiot jest wspótodpowiedzialny za inne podmioty. Można zaryzykować opis, że solidarność na nowo określa świat danej społeczności lub wspólnoty. Jeżeli tak, akt solidaryzacji pozwala doświadczać świata obcego, będącego pierwotnie poza możliwością jego zmiany w pojedynkę, jako świata własnego, czyli wspólnego dla danej grupy. Odnosząc się także do horyzontalnej struktury tego aktu, można twierdzić, że podmioty są tutaj zakorzenione i osadzone w określnej rzeczywistości historyczno-kulturowej oraz w danym języku. Opis ten wydaje się korespondować z opisami „świata domowego” (Heimwelt), przedstawionymi przez Steinbocka $\mathrm{w}$ jego interpretacji fenomenologii generatywnej ${ }^{54}$. O ile jednak amerykański filozof kładzie nacisk na historyczność stwarzania domu i oswajania otaczającego świata, o tyle fenomen solidarności pokazuje, że doświadczenie świata jako wspólnego realizuje się w złożonym akcie, który określa to doświadczenie w modi „my”. Nie idzie przy

53 Jak ujmuje to Caminada, „We-mode of experience or the postulation of a capacity for we-intentionality is only the point of departure of a complex phenomenological analysis: »discovering the We « means, for Husserl, to uncover the sedimentation of the most basic associations or groupings that enable the constitution and the development of a common world". E. Caminada, dz. cyt., 291.

54 Zob. A.J. Steinbock, Home and Beyond: Generative Phenomenology after Husserl, Evanston 1995, 188, 232. 
tym o spontaniczne uznanie świata jako świata wspólnoty, ale to, że świata doświadcza się we wspólnocie, za członków której jest się współodpowiedzialnym przez działanie w grupach na rzecz realizacji danych wartości.

\section{ZAKOŃCZENIE}

Głównym celem tego artykułu była próba analizy fenomenologicznej solidarności jako zjawiska społecznego. Odróżniając solidaryzację subiektywną od intersubiektywnej, starałem się pokazać, że akt solidaryzowania się konstytuuje grupy i określa doświadczenie świata w modi „my”. To ogólne określenie oczywiście nie wyklucza, że także solidaryzacja intersubiektywna ma różne formy i stopnie: od np. solidaryzowania się z przyjacielem, po solidaryzowanie się całych klas społecznych i wspólnot narodowych. Tym, co łączy różne formy solidaryzacji jest dążenie do stworzenia podmiotowości wyższego rzędu. Solidaryzując się mianowicie podmiot konstytuuje nowy sens doświadczenia. Jest to więc celowościowy proces, w którym przekracza się subiektywne uposażenie i preferencje, uznając, że jest się współodpowiedzialnym za otaczającą rzeczywistość. Dlatego można konkludować, że akt solidaryzowania się jest $\mathrm{w}$ istocie transcendowaniem egotycznego, czyli zorientowanego na pojedynczy podmiot, doświadczania świata. Taki opis jest jednak wciąż niepełny, bo - jak się wydaje - w zasadzie każdy akt świadomości jest aktem transcendencji, ponieważ charakteryzuje się intencjonalnością. Czym więc akt solidaryzacji wyróżnia się na tle innych aktów?

Odpowiadając na to pytanie, krytycznie odniosłem się do propozycji Ingardena i Tischnera, którzy nie potrafili rozwiązać problemu mostu. Problem ten dotyczy nieuzasadnionego wyprowadzenia solidarności intersubiektywnej z solidarności subiektywnej. Nie ulega wątpliwości, że te historyczne dociekania mogłyby być pogłębione 
i objąć analizy solidarności sformułowane przez Wojtyłę⿸5 lub Patočkę ${ }^{56}$. Celem moim jednak nie była rekonstrukcja problemu solidarności w tradycji fenomenologicznej, lecz raczej próba opisu solidarności jako złożonego aktu, który łączy aspekty poznawcze, wolitywne i afektywne. Podobna droga odrzuca problem mostu jako pozorny, ponieważ, jak starałem się pokazać, solidarność jest autonomicznym fenomenem, który nie jest znaczący tylko poprzez akty subiektywne. Wręcz przeciwnie, bo istotą solidarności jako zjawiska społecznego jest jego intersubiektywność, która realizuje się we wspólnym działaniu. Nie twierdzę oczywiście, że każdy przypadek wspólnego działania ma być rozumiany jako solidaryzacja. Teza taka byłaby nieuzasadniona. Tym, co odróżnia akt solidaryzowania się od prostego przypadku wspólnego działania są wyobrażeniową treść tego aktu, jego protencyjny horyzont czasowy oraz aspekt normatywny, który realizuje się w przeżywaniu współodpowiedzialności za innych członków grupy i dążeniu do realizacji określonych przez wspólnotę wartości. Przeżywanie współodpowiedzialności jest korelatem działania podmiotu na rzecz dobra wspólnego, który zawiesza indywidualne preferencje. Tak ujęty akt solidaryzowania się konstytuuje podmiotowość wyższego rzędu, co oznacza, że podmiot doświadcza świata w modi „my”. Wydaje się, że podobny opis solidarności, chociaż wciąż szkicowy, umożliwia bardziej adekwatne zrozumienie tego zjawiska.

\section{BIBLIOGRAFIA}

Bukowski J., Próba pogodzenia intersubiektywności zidealizmem transcendentalnym u Edmunda Husserla, Studia Filozoficzne 2(1984)219, 101-114.

Bukowski J., Zarys filozofii spotkania, Kraków 1987.

55 W szczególności zob. K. Wojtyła, Osoba i czyn oraz inne studia antropologiczne, red. T. Styczeń et al., Lublin 2000, 316-323.

56 W sprawie koncepcji „solidarności zachwianych”, zob. J. Patočka, Eseje heretyckie z filozofii dziejów, tłum. z czeskiego A. Czcibor-Piotrowski, E. Szczepańska, J. Zychowicz, Warszawa 1998, 185-187. 
Buksiński T., Odetyki solidarności do etycznego egoizmu, Filo-Sofija 29(2015)2, 37-57. Caminada E., Husserl on Groupings: Social Ontology and the Phenomenology of We-Intentionality, w: Phenomenology of Sociality: Discovering the 'We', red. T. Szanto, D. Moran, New York 2016, 281-295.

Chelstrom E., Social Phenomenology. Husserl, Intersubjective, and Collective Intentionality, Lanham, Boulder, New York, Toronto, Plymouth 2013.

Dobrzański D., Zasada solidarności. Studium z filozofii spotecznej, Poznań 2013.

Galarowicz J., Paradoks egzystencji etycznej. Inspiracje: Ingarden - Wojtyta - Tischner, Kraków 2009.

Gołaszewska M, Romana Ingardena filozofia moralności, Etyka (1971)9, 113-144.

Gubser M., The Far Reaches. Phenomenology, Ethics, and Social Renewal in Central Europe, Stanford 2014.

Husserl E., Badania logiczne. Tom II. Badania dotyczace fenomenologii i teorii poznania. Częśs I, przeł., wstępem poprzedził i przypisami opatrzył J. Sidorek, przekład przejrzał A. Półtawski, Warszawa 2000.

Husserl E., Erste Philosophie (1923/24). Zweiter Teil. Theorie derphänomenologischen Reduktion, red. R. Boehm, Den Haag 1958.

Husserl E., Fenomenologia i antropologia, Archiwum Historii Filozofii i Myśli Społecznej (1987)32, 333-346.

Husserl E., Idee czystej fenomenologii i fenomenologicznej filozofii, przeł. i przypisami opatrzyła D. Gierulanka, tłumaczenie przejrzał i wstępem poprzedził R. Ingarden, Warszawa 1967.

Husserl E., Medytacje kartezjańskie z dodaniem uwag krytycznych Romana Ingardena, przeł. i przypisami opatrzył A. Wajs, przekład przejrzał i wstępem poprzedził A. Półtawski, Warszawa 1982.

Husserl E., Postowie do moich "Idei czystej fenomenologii i fenomenologicznej filozofii”, tłum. J. Szewczyk, w: Drogi wspótczesnej filozofii, wybrał i wstępem opatrzył M.J. Siemek, Warszawa 1978, 49-81.

Husserl E., Vorlesungen über Ethik und Wertlehre. 1908-1914, red. U. Melle, Dordrecht, Boston, London 1988.

Husserl E., Zur Phänomenologie der Intersubjektivität. Texte aus dem Nachlass. Zweiter Teil: 1921-1928, red. I. Kern, Den Haag 1973.

Husserl E., Zur Phänomenologie der Intersubjektivität. Texte aus dem Nachlass. Dritter Teil: 1929-1935, red. I. Kern, Den Haag 1973.

Ingarden R., O odpowiedzialności i jejpodstawach ontycznych, w: tenże, Ksiażeczka ocztowieku, Kraków 1998, 71-169.

Ingarden R., Wyktady z etyki, wybrał, opracował i wstępem poprzedził A. Węgrzecki, Warszawa 1989. 
Jadacki J.J., Odpowiedzialnośc $i$ istnienie świata, Studia Filozoficzne 5(1973)90, 245-257.

Judycki S., Intersubiektywności i czas. Przyczynek do dyskusji nad póżna faza pogląóww Edmunda Husserla, Lublin 1990.

Mensch J.R., Intersubjectivity and Transcendental Idealism, New York 1988.

Patočka J., Eseje heretyckie z filozofii dziejów, tłum. z czeskiego A. Czcibor-Piotrowski, E. Szczepańska, J. Zychowicz, Warszawa 1998.

Płotka W., Analiza struktury i geneza egzystencji: dwie postacie metody fenomenologicznej, Kwartalnik Filozoficzny 40(2012)3, 23-41.

Płotka W., Studia z fenomenologii poznania. Transcendentalna filozofia Edmunda Husserla a problem wiedzy, Gdańsk 2015.

Rosiak M., Z problematyki ontologii formalnej: Fenomenologiczne teorie catości i części, $\mathrm{w}$ : Wprowadzenie do fenomenologii. Interpretacje, zastosowania, problemy. T. II, red. W. Płotka, Warszawa 2014, 377-409.

Römpp G., Husserls Phänomenologie der Intersubjektivität. Und ibre Bedeutung für eine Theorie intersubjektiver Objektivität und die Konzeption einer phänomenologischen Philosophie, Dordrecht, Boston, London 1992.

Sokolowski R., The Logic of Parts and Wholes in Husserl's Investigations, Philosophy and Phenomenological Research 4(1968)28, 537-553.

Steinbock A.J., Home and Beyond: Generative Phenomenology after Husserl, Evanston 1995.

Stróżewski W., Nad „Książeczkq o człorwieku”, Studia Filozoficzne 9(1973)94, 123-126.

Szanto T., Husserl on Collective Intentionality, w: The Phenomenological Approach to Social Reality, red. A. Salice, H.B. Schmid, Dordrecht 2016, 145-172.

Schutz A., Das Problem der transzendentalen Intersubjektivität bei Husserl, Philosophische Rundschau 5(1957), 81-107.

Światała I.M., Ks. Józef Tischner: Etyka solidarności, czyli chrześcijański model rzeczywistości spotecznej i politycznej, w: Etyka solidarności. W 10. rocznice śmierci ks. Józefa Tischnera, red. W. Słomski, Warszawa 2010, 89-105.

Taylor C., Kilka uwag na temat solidarności, Znak 52(2000)8, 22-34.

Tischner J., Etyka solidarności, w: tenże, Etyka solidarności oraz Homo sovieticus, Kraków 2005, 9-138.

Tischner J., Fenomenologia świadomości egotycznej, w: tenże, Studia z filozofii świadomości, opracował naukowo i przedmową opatrzył A. Węgrzecki, Kraków 2006, 129-422.

Tischner J., Impresje aksjologiczne, w: tenże, Świat ludzkiej nadziei, Kraków 2005, 148-166. 
Węgrzecki A., O doświadczeniu aksjologicznym, w: W kręgu fllozofii Romana Ingardena. Materiaty z konferencji naukowej Kraków 1985, red. W. Stróżewski, A. Węgrzecki, Warszawa, Kraków 1995, 161-166.

Węgrzecki A., Podmiotowość i wartości, w: Roman Ingarden a flozofia naszego czasu, red. A. Węgrzecki, Kraków 1995, 148-160.

Węgrzecki A., Tischner i Ingarden, Kwartalnik Filozoficzny 35(2007)1, 77-88.

Wojtyła K., Osoba i czyn oraz inne studia antropologiczne, red. T. Styczeń et al., Lublin 2000.

Zahavi D., Husserl und die transzendentale Intersubjektivität. Eine Antwort auf die sprachpragmatische Kritik, Dordrecht, Boston, London 1996.

\title{
AN OUTLINE OF THE PHENOMENOLOGY OF SOLIDARITY: ON THE GENESIS OF THE CONSTITUTING OF A GROUP
}

\begin{abstract}
The article is an attempt at a phenomenology of solidarity as a social phenomenon. The author differentiates subjective and intersubjective solidarization, and he emphasizes that the latter concerns the process of the constituting of a group. The article is divided into three main parts. In the first part, so-called bridge problem is analyzed. The problem concerns a justificatory transition of the analysis from subjective solidarization to the intersubjective one. A point of departure are here theories of Ingarden and Father Tischner. Next, the author presents a description of the structure and elements of solidarity as elements of a complex act. At this basis, the author formulates an outline of an alternative approach to solidarity, namely as the constituting groups, and as a relation to the world as a common world.
\end{abstract}

Keywords: solidarity, solidarization, communality, constitution, collective intentionality, Husserl

\footnotetext{
Witold PŁotKA

w.plotka@uksw.edu.pl

Uniwersytet Kardynała Stefana Wyszyńskiego w Warszawie, Instytut Filozofii

Wóycickiego 1/3, 01-938 Warszawa
}

DOI: $10.21697 /$ spch.2018.54.4.02 